\title{
PURIFICATION AND CHARACTERIZATION OF BACTERIOCIN PRODUCED BY DIFFERENT Lactobacillus SPECIES ISOLATED FROM FERMENTED FOODS
}

\author{
SARANYA S. AND HEMASHENPAGAM N.* \\ Department of Microbiology, Hindusthan College of Arts and Science, Coimbatore- 641 028, TN, India. \\ ${ }^{*}$ Corresponding Author: Email- drhemashenpagam@gmail.com
}

Received: December 27, 2011; Accepted: January 10, 2013

\begin{abstract}
The aim of the study was to isolate and characterize bacteriocin producing Lactic acid bacteria (LAB) from fermented foods products and to exploit their potential as biopreservatives. The two Lactobacillus strains namely $L$. plantarum and $L$. fermentum exhibiting wide spectrum of activity against closely related strain were selected and screened for their bacteriocin producing ability. Cell free supernatant fluid collected from both the isolates and several gram positive and gram negative pathogens such as S.aureus, E.coli, P.aeruginosa, S.pneumoniae, Klebisella, and proteus were inhibited by the inhibitory action of bacteriocins in study. The bacteriocinogenic potential in these strains appeared non-inducible and increase in their titer was observed after exposure to different concentrations of UV light. The concentrated crude bacteriocin samples subjected to ammonium sulphate precipitation resulted in an increased activity and high protein yield. By nondenaturing gel a band of approximately $8 \mathrm{KDa}$ for $L$. fermentum and band corresponding to $37 \mathrm{KDa}$ in $L$. plantarum was seen. Physio-chemical characterization of the partially purified bacteriocin samples indicated heat $\left(121^{\circ} \mathrm{C}\right.$ for $\left.60 \mathrm{~min}\right)$ and acidic $\mathrm{pH}$ stability $(\mathrm{pH} 2-6)$ of bacteriocin. Exposure to different carbon and other substations also resulted in increased bacteriocin titer. The high performance liquid chromatography was performed for $L$. plantarum.
\end{abstract}

Keywords- Lactic acid Bacteria, Antagonistic acivity, Mutation, TLC, HPLC

Citation: Saranya S. and Hemashenpagam N. (2013) Purification and Characterization of Bacteriocin Produced by Different Lactobacillus Species Isolated from Fermented Foods. International Journal of Microbiology Research, ISSN: 0975-5276 \& E-ISSN: 0975-9174, Volume 5, Issue 1, pp.-341-348. DOI: 10.9735/0975-5276.5.1.341-348.

Copyright: Copyright@2013 Saranya S. and Hemashenpagam N. This is an open-access article distributed under the terms of the Creative Commons Attribution License, which permits unrestricted use, distribution and reproduction in any medium, provided the original author and source are credited.

\section{Introduction}

Lactic acid bacteria are a diverse group of genera which can be characterised as Gram-positive, catalase negative, non-sporulating, non-pigmented mesophils [1]. The tolerated temperature range is generally between 5 and $50^{\circ} \mathrm{C}$, with the optimum for most strains being about $30^{\circ} \mathrm{C}$ [2]. Shape is variable, from cocci through to elongated rods. Although metabolically similar, there is a lack of DNA homology between them. They lack the pathways for nitrate reduction, for the production of catalase and for the production of cytochromes and other pigments. They also have a complex and variable nutritional requirement differing according to species [3].

Lactic acid is an organic acid that is produced as a result of fermentation metabolism by the lactic acid bacteria [4]. Many chemical substances are constantly involved in the biochemical processes going on in living systems. Among these, Lactic acid serves as an important metabolite of an equally important energy yielding process [5]. Lactic acid is a carboxylic acid with a chemical formula $\mathrm{CH}_{3} \mathrm{CHOHCOOH}$ and is a colorless liquid organic acid [6]. It is widely used chemical that has found application in many industries and various commercial purposes. It is used in leather tanning and textile dyeing and in making inks, solvents and lacquers [6]. Lactic acid is also used as acidulate, flavoring, pH buffering agent or inhib- itor of bacterial spoilage in processed foods. The esters of lactic acid are used in baking foods, as emulsifying agents [6,7]. Lactic acid bacteria produce various compounds such as organic acids, diacetyl, hydrogen peroxide and bacteriocin or bactericidal proteins during lactic acid fermentations [8,9].The production of lactic acid can be done in two ways which are chemical synthesis and carbohydrate fermentation [6].

Lactic acid bacteria exert strong antagonistic activity against many microorganisms including food spoilage organisms and pathogens. In addition, some strains may contribute to the preservation of fermented foods by producing bacteriocins [10]. Research on Bacteriocins from lactic acid bacteria has expanded during the last decades to include the use of bacteriocins or the producer organisms as natural food preservatives [11]. Bacteriocins of LAB have been classified into four structural classes, namely I, II, III and IV [12].

Bacteriocins are ribosomally synthesized, extracellularly released bioactive peptides or peptide complexes (usually 30-60 amino acids) which have a bactericidal or bacteriostatic effect on other (usually closely related) species [13]. Bacteriocins are generally considered to act at the cytoplasmic membrane and dissipate the proton motive force through the formation of pores in the phospholipid bilayer [14]. 
Antimicrobial substances produced by lactic acid bacteria can be divided into two main groups: low molecular mass substances with molecular mass $<1000 \mathrm{Da}$ and high molecular mass substances with molecular mass $>1000 \mathrm{Da}$, such as bacteriocins. All nonbacteriocin antimicrobial substances from $L A B$ are of low molecular mass [15].

The bacteriocins are low molecular mass peptides and it has been reveled that the bacteriocin Bavaricin A consists of 41 amino acid residues and has a calculated molecular mass above $4300 \mathrm{Da}$; SDS-PAGE reveals a molecular mass of $3500-4000 \mathrm{Da}$ [18]. It has been also showed that the molecular mass of reutericyclin is $3100 \mathrm{Da}$, indicating that they form stable multimers in aqueous solutions, even in the presence of denaturing agents or organic solvents [16]. Further purification was performed by thin-layer chromatography [17].

Lactic acid occurs in fermented products as a result of hydrolysis, biochemical metabolism, and microbial activity. Quantitative determination of lactic acid is important in fermented products for technical, nutritional, sensorial, and microbial reasons. Trimetric methods, gas chromatography, colorimetric analysis and enzymatic methods are examples of techniques that are used for analyses of organic acids [19]. However, because simplicity and speed of analysis, the HPLC techniques is an attractive method, which requires a minimum of sample preparation prior to separation and permits quantitative determination of organic acids in short time.

This study was attempted to isolate lactic acid producing strains from fermented food products. These strains were identified and initially tested for their probiotic properties. The inhibitory effect of these strains on both Gram-positive and Gram-negative pathogenic bacteria was further investigated. These aspects are used in the study of antimicrobials for their production and characterization.

\section{Materials and Methods}

\section{Isolation and Identification of Lactobacillus Species}

A total of 25 fermented milk products were randomly collected in sterilized glass bottles [20]. The strains were stored at $-80^{\circ} \mathrm{C}$ in MRS broth medium [21]. Before experimental use the cultures were propagated twice in MRS at $37^{\circ} \mathrm{C}$. The transfer inoculum was $1 \%$ $(\mathrm{v} / \mathrm{v})$ of $16 \mathrm{~h}$ culture grown in fresh medium.

The sample was serially diluted to $10^{-5-10^{-6}}$ using sterile distilled water and $0.1 \mathrm{ml}$ were taken for spread plate and $1 \mathrm{ml}$ were taken for pour plate and the different diluents was plated on to sterile deMann Rogosa and Sharpe (MRS) agar. The MRS plates were maintained in microaerophilic condition and incubated at $37^{\circ} \mathrm{C}$ for 48 Hrs. The isolates were identified using standard morphological, cultural and biochemical reactions [22].

\section{Morphological Biochemical Characterization}

Gram staining was done to identify the morphology structure and biochemical test namely MRVP, oxidase and catalase test was done.

\section{Carbohydrate Fermentation}

To determine the products of sugar fermentation, a carbohydrate fermentation broth was prepared at $\mathrm{pH}$ 7.4. This broth contains 3 essential ingredients: $0.5 \%-1.0 \%$ of the carbohydrate to be tested (e.g. lactose or glucose), nutrient broth, and the $\mathrm{pH}$ indicator phenol red. The nutrient broth, which is a light red color, supports the growth of most organisms whether they are able to ferment the sugar or not.
Growth at 8 and $15^{\circ} \mathrm{C}$ in tubes containing MRS broth and fermentation of carbohydrates were determined. The carbohydrates tested were $\mathrm{D}(+)$ cellobiose (Difco), $\mathrm{D}(+)$ galactose (Difco), xylose (Difco), fructose (Difco), maltose (Difco), mannitol (Difco), Trehalose (Difco), D(-) raffinose (Difco), ribose (Difco), sorbitol (Difco) and glucose (Difco).

\section{Determination of Antibiotic Resistance}

Antibiotic disc were employed to determine the pattern of antibiotic resistance of Lactobacillus strains. The disc includes gentamycin $(10 \mu \mathrm{g})$, ketoconozole $(30 \mu \mathrm{g})$, rifampicin $(10 \mu \mathrm{g})$, novobiocin $(10 \mu \mathrm{g})$, flucozonazole $(15 \mu \mathrm{g})$, chloramphenicol $(30 \mu \mathrm{g})$, and amphotericin $(30 \mu \mathrm{g})$. These discs were placed on the solidified agar surface (Muller Hinton Agar) swabbed with the lactobacillus strains (10-6 $\mathrm{cfu} / \mathrm{ml}$ suspension of freshly grown strain).

The plates were incubated aerobically for $24 \mathrm{Hrs}$. at $37^{\circ} \mathrm{C}$ [23]. Resistance was determined according to the reference zone diameter interpretative standards of National Committee for Clinical Laboratory Standards [24]. Inhibition zones were recorded and compared to standard values.

\section{Assessment of Bacteriocin Production by Antagonistic Activi- ties of the Strains of Lactobacillus Spp. Isolates}

Antimicrobial effects of presumptive strains of Lactobacillus spp. on the test isolates Escherichia coli, Staphylococcus aureus, Pseudomonas aeroginosa, Streptococcus, Proteus spp, Klebsiella pneumonia were determined by the agar well diffusion method.

\section{Quantitative Studies on Production of other Antimicrobial Agents by the test Isolates}

\section{Quantitative Estimation of Lactic Acid}

The production of lactic acid was determined by transferring $25 \mathrm{ml}$ of broth cultures of test organisms (Lactobacillus strains) into $100 \mathrm{ml}$ flasks. This was titrated with $0.1 \mathrm{~N} \mathrm{NaOH}$ and $1 \mathrm{ml}$ of phenolphthalein indicator $(0.5 \%$ in $5 \%$ alcohol) till the end point appears pink colour. The titratable acidity was calculated as lactic acid \% w/v [35]. Each $\mathrm{ml}$ of $1 \mathrm{n} \mathrm{NaOH}$ is equivalent to $90.08 \mathrm{mg}$ of lactic acid. The titratable acidity was then calculated as stated in AOAC [25].

\section{Quantitative Estimation of Diacetyl}

Diacetyl production was determined by transferring $25 \mathrm{ml}$ of broth cultures of test organisms into $100 \mathrm{ml}$ flasks. Hydroxylamine solution $(7.5 \mathrm{ml})$ of 1 molar was added to the flask and to a similar flask for residual titration. Both flasks were titrated with $0.1 \mathrm{M} \mathrm{HCl}$ to a greenish yellow end point using bromophenol blue as indicator [36]. The equivalence factor of $\mathrm{HCl}$ to diacetyl is $21.52 \mathrm{mg}$. The concentration of diacetyl produced was calculated using the A.O.A.C. [25].

\section{Quantitative Estimation of Hydrogen Peroxide}

Hydrogen peroxide production was determined by measuring $25 \mathrm{ml}$ of broth cultures of the test organisms into a $100 \mathrm{ml}$ flask. To this was added $25 \mathrm{ml}$ of dilute $\mathrm{H}_{2} \mathrm{SO}_{4}$. This was then titrated with $0.1 \mathrm{M}$ $\mathrm{KMnO}_{4}$ (potassium permanganate). Each milliliter of $0.1 \mathrm{~N} \mathrm{KMnO}_{4}$ is equivalent to $1.701 \mathrm{mg}$ of $\mathrm{H}_{2} \mathrm{O}_{2}$. A de-colorization of the sample was regarded as the end point. The volume of $\mathrm{H}_{2} \mathrm{O}_{2}$ produced was then calculated A.O.A.C. [25].

\section{Mutation Studies to Increase the Production of Bacteriocin Production}

The effect of mutation was studied under UV light on the bacteriocinogenic potential of the strains. To analyze the activity of mutation, 
a $10 \mathrm{ml}$ aliquot of cultured broth was placed in a sterile petridish and these plates were exposed to short-wave UV light $(254 \mathrm{~nm})$ from a electric germicidal bulb at a distance of $20 \mathrm{~cm}$. The time of exposure ranges from 0 to $20 \mathrm{~min}$ [26]. After each time interval, bacteriocin activity was analyzed as described below.

The mutated aliquots from each plate was taken in different concentrations as $25 \mu \mathrm{l}, 50 \mu \mathrm{l}, 75 \mu \mathrm{l}$ and $100 \mu \mathrm{l}$ respectively and plated on to the solidified agar plates. These plates were incubated at $37^{\circ} \mathrm{C}$ for $24 \mathrm{Hrs}$. and the results were compared with the standards and the zone of inhibition was measured.

\section{Optimization Studies on Physio-Chemical Characterization of Partially Purified Bacteriocin Sample}

To test the heat sensitivity, culture supernatant (cell-free filtrate mentioned above) containing bacteriocin was heated for $10 \mathrm{~min}$ at $60^{\circ} \mathrm{C}, 70^{\circ} \mathrm{C}, 80^{\circ} \mathrm{C}, 90^{\circ} \mathrm{C}, 100^{\circ} \mathrm{C}$ and $121^{\circ} \mathrm{C}$ and the bacteriocin activity was tested against various bacterial pathogens Escherichia coli, Staphylococcus aureus, Pseudomonas aeroginosa, Klebsiella pneumonia, Streptococcus and Proteus spp by agar well diffusion assay.

The sensitivity of bacteriocins to different $\mathrm{pH}$ was tested by adjusting the $\mathrm{pH}$ of culture supernatant (containing bacteriocins) in the range of $\mathrm{pH} 3.0,4.5,7.0$ and 9.0 with $4 \mathrm{M}$ hydrochloric acid $(\mathrm{HCl})$ and /or $4 \mathrm{M}$ sodium hydroxide $(\mathrm{NaOH})$ and then production of bacteriocins was detected by agar well diffusion method against Escherichia coli, Staphylococcus aureus, Pseudomonas aeroginosa, Klebsiella pneumonia, Salmonella typhimurium and Proteus spp.

\section{Effect of Other Parameters}

Overnight grown culture of $L$. plantarum was inoculated into $100 \mathrm{ml}$ of MRS broth with varying concentrations of different carbon sources such as xylose $2-4 \%$, glucose $2-4 \%$, sorbitol $2-4 \%$, lactose $2-4 \%$, maltose $2-4 \%$, mannose $2-4 \%$, galactose $2-4 \%$, sucrose $2-$ $4 \%$ and fructose $2-4 \%$ and incubated at $37^{\circ} \mathrm{C}$ for $16 \mathrm{Hrs}$. and $L$. plantarum was inoculated into $100 \mathrm{ml}$ of MRS broth with varying concentrations of different substitutes such as yeast extract $0.5-2 \%$, MgSO4 0.5\%, Tween $800-2 \%$ and SDS $0.25-0.5 \%$ and incubated at $37^{\circ} \mathrm{C}$ for $16 \mathrm{Hrs}$.

\section{Estimation of Protein and Molecular Size Determination by SDS-PAGE}

The protein content of the Lactobacillus strains was estimated using Lowry, et al. method. Partial purification was done using ammonium sulphate. The strains were mixed with ammonium sulphate at different concentration $20 \%, 40 \%, 60 \%, 80 \%$ respectively. This mixture was allowed to stand for $1 \mathrm{hr}$. at $4^{\circ} \mathrm{C}$. The sample was centrifuged at $10,000 \mathrm{rpm}$ for $15 \mathrm{~min}$. The supernatant was brought to saturation and the pellet was dissolved in $100 \mathrm{Mm} / \mathrm{L}$ of potassium phosphate buffer and stored at $4^{\circ} \mathrm{C}$ for further use. The above sample was taken for molecular size determination using SDS-PAGE. The bands were compared with the marker.

To separate the antimicrobial compounds present in the LAB strains TLC was performed as described by sadasivan and Manikam [27]. Further purification of the LAB fractions was done by HPLC with an isocratic gradiant.

\section{Result}

In the present study, a total of 25 different fermented food samples like paneer, milk, curd, butter and cheese were collected to isolate Lactobacillus species. The mean $\mathrm{pH}$ values of these samples were around 6 to 6.5 . All isolates were tested for the following as shown below [Table-1], [Fig-1], [Table-2] and [Table-3].

Table 1- LAB species isolated from different food samples

\begin{tabular}{|c|c|c|c|}
\hline \multicolumn{2}{|c|}{ S. No. Fermented Food Sample } & Code & LAB Isolated \\
\hline & \multirow{4}{*}{ Cheese } & C1 & L.fermentum \\
\hline \multirow{5}{*}{1} & & C2 & L.casei \\
\hline & & C3 & L.plantarum \\
\hline & & C4 & L.brevis \\
\hline & \multirow{4}{*}{ Butter } & B1 & L.casei \\
\hline & & B2 & L.fermentum \\
\hline \multirow{4}{*}{2} & & B3 & L.plantarum \\
\hline & & B4 & L.brevis \\
\hline & \multirow{4}{*}{ Paneer } & P1 & L.fermentum \\
\hline & & P2 & L.casei \\
\hline \multirow{4}{*}{3} & & P3 & L.fermentum \\
\hline & & P4 & L.plantarum \\
\hline & \multirow{4}{*}{ Milk } & M1 & L.casei \\
\hline & & M2 & L.plantarum \\
\hline \multirow{3}{*}{4} & & M3 & L.fermentum \\
\hline & & M4 & L.brevis \\
\hline & \multirow{4}{*}{ Curd } & CU1 & L.fermentum \\
\hline \multirow{3}{*}{5} & & CU2 & L.plantarum \\
\hline & & CU3 & L.casei \\
\hline & & CU4 & L.brevis \\
\hline
\end{tabular}

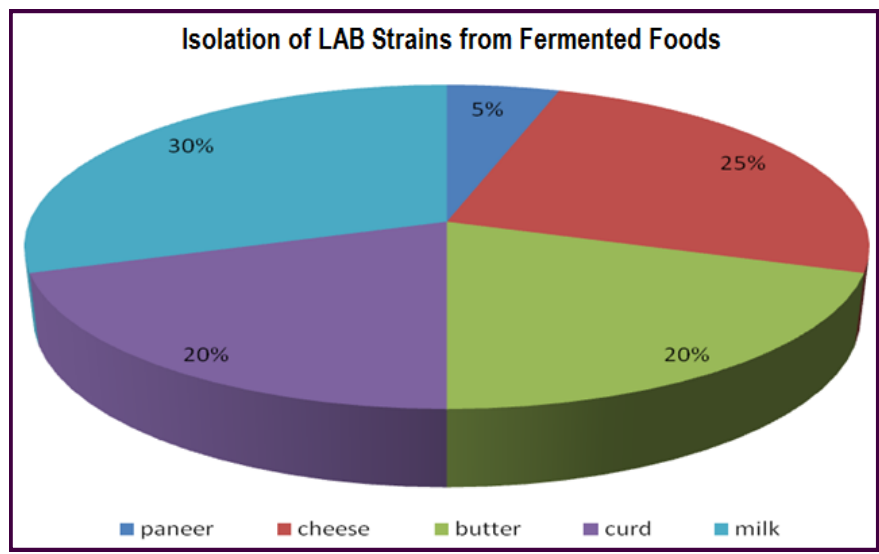

Fig.1- Graphical view of LAB species isolated from different food samples

\section{Presumptive Identification of the Test Isolates}

The four presumptive bacteriocin producers were characterized and identified to species level utilizing carbohydrate fermentation profiles, biochemical and physiological characteristics as stated below

\section{Gram Staining}

The bacteriocin-producing strains were identified based on the morphologyical studies by Gram staining. All the LAB isolates showed the presence of Gram-positive rods when viewed under the phase contrast microscope. The results interrupted on the basis of staining technique [Table-2]

Table 2- Morphological studies based on Gram staining

\begin{tabular}{|lcc|} 
S. No & LAB isolates & Morphological features \\
\hline 1 & Lactobacillus casei & Gram positive rods \\
2 & L. plantarum & Gram positive rods \\
3 & L. brevis & Gram positive rods \\
4 & L. fermentum & Gram positive rods \\
\hline
\end{tabular}

\section{Biochemical Tests for LAB Isolates}

Various biochemical test were performed to isolate and identify the $L A B$ strains. Based on these studies, the test isolates showed the absence of catalase, oxidase, indole production and it showed posi- 
tive result for methyl red test Voges proskaur test and nitrate reduction. All the above results showed the presence of $L A B$ isolates indicated in [Table-3].

Table 3- Biochemical test for $L A B$ isolates

\begin{tabular}{|llllllll|} 
No & Lactobacillus spp & Indole & MR & VP & Nitrate reduction & Catalase & Oxidase \\
\hline 1 & L. plantarum & $-\mathrm{ve}$ & $+\mathrm{ve}$ & $-\mathrm{ve}$ & $+\mathrm{ve}$ & $-\mathrm{ve}$ & $-\mathrm{ve}$ \\
2 & L. fermentum & $-\mathrm{ve}$ & $+\mathrm{ve}$ & $-\mathrm{ve}$ & $+\mathrm{ve}$ & $-\mathrm{ve}$ & $-\mathrm{ve}$ \\
3 & L. casei & $-\mathrm{ve}$ & $+\mathrm{ve}$ & $-\mathrm{ve}$ & $+\mathrm{ve}$ & $-\mathrm{ve}$ & $-\mathrm{ve}$ \\
4 & L. brevis & $-\mathrm{ve}$ & $+\mathrm{ve}$ & $-\mathrm{ve}$ & $+\mathrm{ve}$ & $-\mathrm{ve}$ & $-\mathrm{ve}$ \\
\hline
\end{tabular}

\section{Carbohydrate and Sugar Fermentation Profiles}

Based on the carbohydrate fermentation patterns, the LAB strains showed no gas production from sugars. Out of the 4 isolated $L A B$ strains, $L$. plantarum and $L$. fermentum showed maximum acid production compared to $L$. casei and $L$. brevis. The fermentation profile are listed in [Table-4].

Table 4- Sugar Fermentation test LAB isolate Cellu Glu Galac Mann Malt Rham Raffi Ribo Sorb Treh Fruc Xylo

\begin{tabular}{lllllllllllll} 
S1 & + & - & + & + & + & + & + & + & - & - & - & - \\
S2 & + & + & + & + & + & - & + & + & + & + & + & + \\
S3 & + & - & + & + & + & + & + & + & - & + & + & + \\
S4 & - & + & - & - & - & - & - & - & - & - & - & + \\
\hline
\end{tabular}

S1 - L. plantarum, S2 - L. fermentum, S3 - L. casei, S4 - L. brevis : Cellu-cellulobiose, glu-glucose, galac-galactose, mann-mannitol, malt-maltose, rham-rhamonase, raff-raffinose, ribo-ribose, sorbsorbitol, treh-trehalose, fruc-fructose, xylo-xylose :(+) - acid production, (-) - no acid production.

On the basis of all the above identification tests the strains isolated from the test samples was identified as Lactobacillus casei, $L$. plantarum, L. brevis, and L. fermentum.

\section{Detection of Antibiotic Resistance of Lactobacillus Species}

The $L A B$ producing strains were then further studied for their antibiotic susceptibility patterns. All the four isolates were susceptible to all of the antibiotic discs used in the study. Results concerning the determination of antibiotic susceptibility of the isolates are given in [Table-5]. In the study, 7 antibiotic discs were used as follows: novobiocin, flucozonazole, gentamycin, rifampicin, ketoconzole, amphotericin and chloramphenicol.

Table 5- Antibiotic sensitivity of different Lactobacillus species

\begin{tabular}{lcccccccc|} 
LAB isolates & $\begin{array}{c}\text { Novo } \\
\text { biocin }\end{array}$ & $\begin{array}{c}\text { Fluco } \\
\text { zonazole }\end{array}$ & \multicolumn{6}{c}{$\begin{array}{c}\text { Genta } \\
\text { mycin }\end{array}$} \\
phenicol & Ampho Rifam Ketoco & $\begin{array}{c}\text { Tetra } \\
\text { tericin }\end{array}$ & nozole cycline \\
L. plantarum & $\mathrm{S}$ & $\mathrm{R}$ & $\mathrm{S}$ & $\mathrm{S}$ & $\mathrm{R}$ & $\mathrm{S}$ & $\mathrm{S}$ & $\mathrm{R}$ \\
L. fermentum & $\mathrm{S}$ & $\mathrm{R}$ & $\mathrm{R}$ & $\mathrm{R}$ & $\mathrm{R}$ & $\mathrm{R}$ & $\mathrm{R}$ & $\mathrm{R}$ \\
L. casei & $\mathrm{R}$ & $\mathrm{R}$ & $\mathrm{R}$ & $\mathrm{R}$ & $\mathrm{R}$ & $\mathrm{R}$ & $\mathrm{R}$ & $\mathrm{R}$ \\
L. brevis & $\mathrm{S}$ & $\mathrm{R}$ & $\mathrm{S}$ & $\mathrm{S}$ & $\mathrm{R}$ & $\mathrm{S}$ & $\mathrm{S}$ & $\mathrm{R}$ \\
\hline
\end{tabular}

$S$ - Sensitive; $R$ - Resistant.

On the basis of result shown in [Table-5], it was observed that $L$. fermentum and $L$. casei showed maximum resistance against antibiotics used in the study.

\section{Antagonistic Activity of Test Isolates}

The antagonistic effects of the bacteriocins on the growth of other Gram-positive and Gram-negative bacteria were determined using the well-diffusion assay. The inhibitory spectrum of the CFS (cellfree supernantant) obtained from the four isolated bacteriocinproducing $L A B$ in this study were able to inhibit the growth of $S$. aureus, E. coli, $P$. aeruginosa, S. pneumoniae, Klebisella, and proteus [Table-6] [Fig-2]. The spectrum of inhibition by $L$. plantarum was significantly wider than $L$. brevis. Both the producer strains were immune to the inhibitory effect of their own bacteriocin as no inhibition was observed when tested against themselves. It was observed that among the 4 test strains $L$. plantarum possess strongest antagonistic activity of $25 \mathrm{~mm}$ against Pseudomonas. This may be due to the production of lactic acid that lowered the $\mathrm{pH}$ of the medium or competition for nutrients, or due to production of bacteriocin or antimicrobial compounds.

Table 6- Antagonistic activity of selected LAB against pathogens

\begin{tabular}{|lcccc|}
\hline Test pathogens & L. fermentum & L. plantarum & L. brevis & L. casei \\
\hline E. coli & $10 \mathrm{~mm}$ & $14 \mathrm{~mm}$ & $6 \mathrm{~mm}$ & $8 \mathrm{~mm}$ \\
Klebsiella & $10 \mathrm{~mm}$ & $7 \mathrm{~mm}$ & $7 \mathrm{~mm}$ & $7 \mathrm{~mm}$ \\
S. aureus & $13 \mathrm{~mm}$ & $10 \mathrm{~mm}$ & $6 \mathrm{~mm}$ & $9 \mathrm{~mm}$ \\
Proteus & $12 \mathrm{~mm}$ & $5 \mathrm{~mm}$ & $15 \mathrm{~mm}$ & $7 \mathrm{~mm}$ \\
Pseudomonas & $15 \mathrm{~mm}$ & $25 \mathrm{~mm}$ & $14 \mathrm{~mm}$ & $8 \mathrm{~mm}$ \\
Streptococcus & $5 \mathrm{~mm}$ & $20 \mathrm{~mm}$ & $12 \mathrm{~mm}$ & $7 \mathrm{~mm}$ \\
\hline
\end{tabular}

*Zone of inhibition in $\mathrm{mm}$

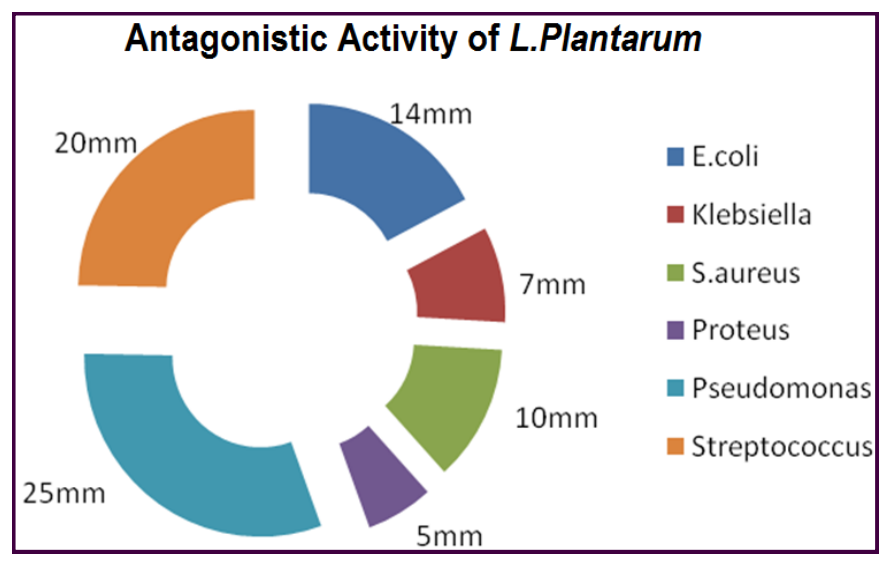

Fig. 2- Graphical view of antagonistic activity of selected $L A B$ against pathogens

\section{Quantitative Studies on Production of Antimicrobial Agents by the Test Isolates}

The LAB species were screened for the quantitative production of lactic acid using normal MRS broth. It was observed that $L$. plantarum produced the highest quantity of lactic acid $(11.6 \pm 0.32 \mathrm{gL}-1)$ at $48 \mathrm{Hrs}$. compared to all other LAB species used in this work with L. brevis having the lowest yield $(8.7 \pm 0.07 \mathrm{gL}-1)$ after $48 \mathrm{Hrs}$. of incubation [Fig-3] [Table-7].

The highest quantity of hydrogen peroxide was produced by $L$. plantarum (15.0 gL-1) after $48 \mathrm{Hrs}$. incubation. After $48 \mathrm{Hrs}$. incubation, it was estimated that the quantity of diacetyl was $18.5 \mathrm{gL}-1$ in L. plantarum [Table-7].

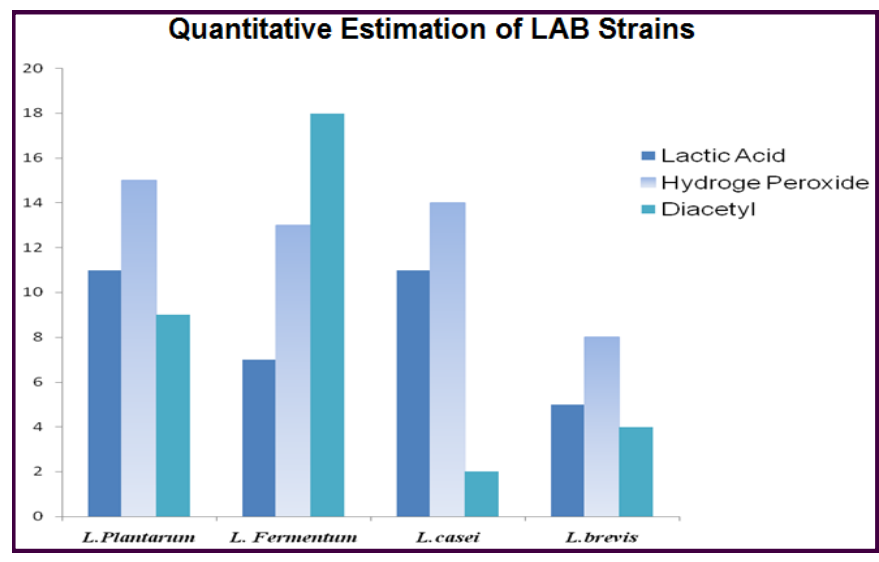

Fig. 3- Antimicrobial production by the $L A B$ isolates ( $\mathrm{gL}-1)$ 
Table 7- Antimicrobial production by the LAB isolates $(g L-1)$

\begin{tabular}{|lccc|}
\hline LAB Isolates & Lactic Acid & Hydrogen Peroxide & Diacetyl \\
\hline L. plantarum & 11.6 & 15 & 18.5 \\
L. plantarum & 11.6 & 15 & 18.5 \\
L. fermentum & 11 & 12 & 10.4 \\
L. fermentum & 11 & 12 & 10.4 \\
L. casei & 10.5 & 20 & 7.5 \\
L. brevis & 8.7 & 10 & 3 \\
\hline
\end{tabular}

\section{Mutation Studies to Increase the Production of Bacteriocin}

[Table-8] shows the effect of mutation on bacteriocin activity. (Exposure to most of UV rays tested resulted in an increase in the bacteriocin titer (by at least one to two fold dilutions).

Table 8- The effect of mutation on bacteriocin activity

\begin{tabular}{|lccc|}
\hline LAB isolates & Mutated strain & Wild strain & Control \\
\hline L.plantarum & $17 \mathrm{~mm}$ & $10 \mathrm{~mm}$ & - \\
L.fermentum & $12 \mathrm{~mm}$ & $9 \mathrm{~mm}$ & - \\
L.casei & $10 \mathrm{~mm}$ & $5 \mathrm{~mm}$ & - \\
L.brevis & $8 \mathrm{~mm}$ & $2 \mathrm{~mm}$ & - \\
\hline
\end{tabular}

*Zone of inhibition in $\mathrm{mm}$, (-) - no growth.

\section{Temperature and pH Stability of Bacteriocins}

The stability of the secreted inhibitory compounds was tested using different temperature treatments [Table-8]. The inhibitory activity was shown to be completely unaffected following heat treatments at $60^{\circ} \mathrm{C}$ to $120^{\circ} \mathrm{C}$. The inhibitory compounds produced by isolates $L$. plantarum and $L$. fermentum were seen to be the most stable to heat treatments up to and beyond $100^{\circ} \mathrm{C}$. L. plantarum maintains its activity even after treatment at $120^{\circ} \mathrm{C}$ for $20 \mathrm{~min}$, a property which is typical for bacteriocins. The sensitivity and stability at high temperatures therefore conclusively identifies these compounds as bacteriocin.

The stability of the inhibitory activity was tested at different $\mathrm{pH}$ values [Table-10]. The bacteriocins produced by isolates, L. plantarum and $L$. fermentum showed greater $\mathrm{pH}$ tolerance and stability than those secreted by other three isolates.

As shown in [Table-9] [Fig-4] and [Table-10] [Fig-5], it was concluded that the use of constituted medium $30^{\circ} \mathrm{C}$ incubation temperature, initial pH 5.5 and for 48 to 60 hours favored the best production of antimicrobial by isolates.

Table 9- Optimization of temperature stability

\begin{tabular}{|lccccc|}
\hline LAB isolates & \multicolumn{5}{c}{ Temperature in ${ }^{\circ} \mathbf{C}$ (zone of inhibition in $\mathbf{~ m m}$ ) } \\
\hline L. plantarum & $\mathbf{6 0}$ & $\mathbf{7 0}$ & $\mathbf{8 0}$ & $\mathbf{9 0}$ & $\mathbf{1 1 0}$ \\
L. fermentum & 20 & 25 & 17 & 19 & 22 \\
L. casei & 12 & 19 & 19 & 15 & 17 \\
L. brevis & 11 & 15 & 13 & 15 & 19 \\
\hline
\end{tabular}

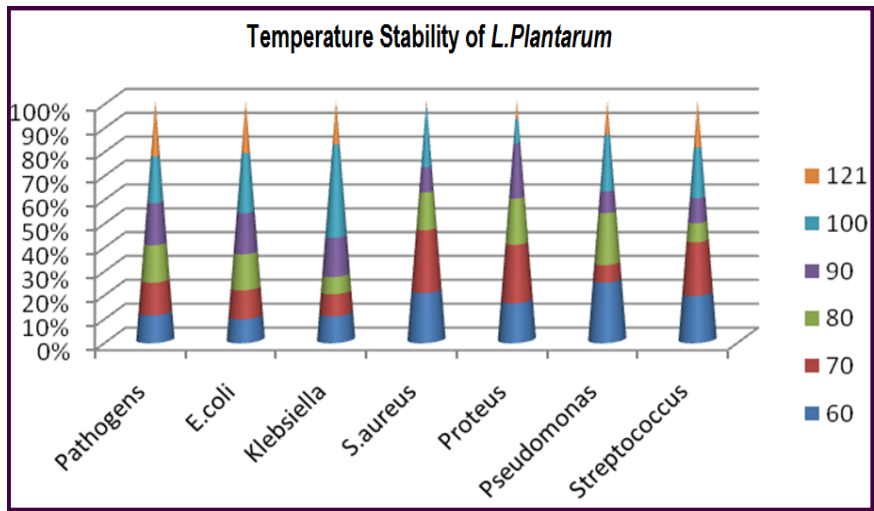

Fig. 4-Graphical view of Optimization of temperature stability
Table 10- Optimization of $\mathrm{pH}$ stability

\begin{tabular}{lcccc|} 
LAB isolates & $\mathbf{3}$ & $\begin{array}{c}\text { pH Range (zone of inhibition in } \mathbf{~ m m} \text { ) } \\
\text { (4.5 }\end{array}$ & $\mathbf{7}$ & $\mathbf{9}$ \\
\hline L. plantarum & 12 & 15 & 25 & 17 \\
L. fermentum & 9 & 12 & 17 & 14 \\
L. casei & 13 & 11 & 19 & 12 \\
L. brevis & 9 & 12 & 18 & 13 \\
\hline
\end{tabular}

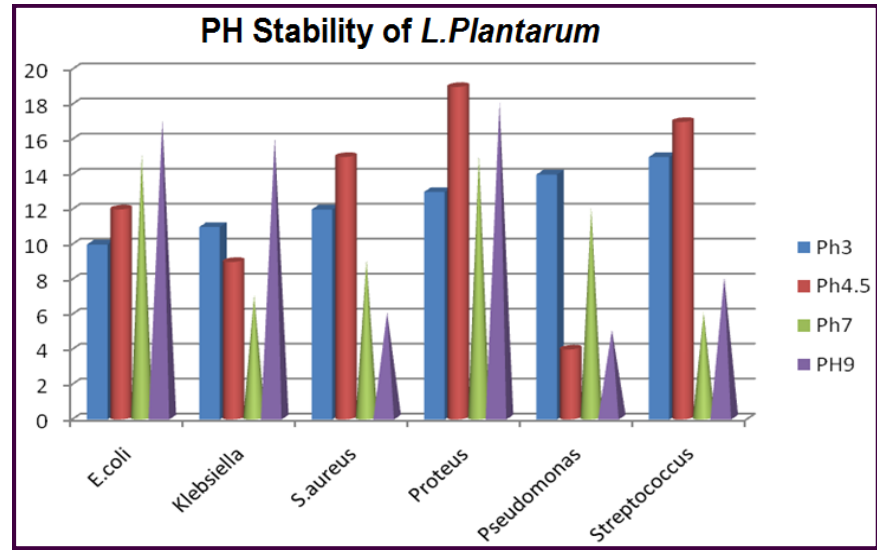

Fig. 5- Graphical view of optimization of pH stability

Effect of Different Carbon Sources and Medium Supplements

Medium composition was also found to play a very important role on bacteriocin production.

Table 11- Bacteriocin activity of Lactobacillus plantarum with different supplements carbon subsitutes in MRS medium.

\begin{tabular}{|c|c|c|c|}
\hline MRS Substitutes & Concentration (\%) & Final pH & Activity (AUMI-1) \\
\hline \multirow[t]{2}{*}{ MRS broth } & & 4.43 & 50 \\
\hline & 2 & 4.98 & 0 \\
\hline \multirow{4}{*}{ Xylose } & 3 & 4.9 & 0 \\
\hline & 3.5 & 4.95 & 0 \\
\hline & 4 & 4.99 & 0 \\
\hline & 2 & 4.38 & 500 \\
\hline \multirow{4}{*}{ Lactose } & 3 & 4.42 & 500 \\
\hline & 3.5 & 4.4 & 2500 \\
\hline & 4 & 4.43 & 2500 \\
\hline & 2 & 4.8 & 50 \\
\hline \multirow[t]{3}{*}{ sorbitol } & 3 & 4.75 & 50 \\
\hline & 3.5 & 4.72 & 50 \\
\hline & 2 & 4.49 & 100 \\
\hline \multirow{4}{*}{ Sucrose } & 3 & 4.5 & 500 \\
\hline & 3.5 & 4.45 & 500 \\
\hline & 4 & 4.47 & 500 \\
\hline & 2 & 4.7 & 100 \\
\hline \multirow{4}{*}{ Galactose } & 3 & 4.65 & 100 \\
\hline & 3.5 & 4.72 & 100 \\
\hline & 4 & 4.71 & 100 \\
\hline & 2 & 4.67 & 100 \\
\hline \multirow{4}{*}{ fructose } & 3 & 4.65 & 100 \\
\hline & 3.5 & 4.71 & 100 \\
\hline & 4 & 4.68 & 100 \\
\hline & 2 & 4.67 & 100 \\
\hline \multirow{4}{*}{ Mannose } & 3 & 4.68 & 100 \\
\hline & 3.5 & 4.62 & 100 \\
\hline & 4 & 4.7 & 100 \\
\hline & 2 & 4.5 & 100 \\
\hline \multirow[t]{4}{*}{ Maltose } & 3 & 4.48 & 500 \\
\hline & 3.5 & 4.52 & 500 \\
\hline & 4 & 4.51 & 500 \\
\hline & 2 & 4.43 & 50 \\
\hline \multirow[t]{3}{*}{ Glucose } & 3 & 4.45 & 50 \\
\hline & 3.5 & 4.43 & 100 \\
\hline & 4 & 4.46 & 100 \\
\hline
\end{tabular}


The components of the production medium peptone, beef extract, yeast extract, glucose, Tween $80, \mathrm{Na}_{2} \mathrm{HPO}_{4}$, sodium acetate, triammonium citrate, $\mathrm{MgSO}_{4} .7 \mathrm{H}_{2} \mathrm{O}$ and $\mathrm{MnSO}_{4}$ were used. The $\mathrm{pH}$ was adjusted to 6.4. This medium corresponds to a complex medium. Various carbon substitutes were tried out. Maximum activity equivalent to $50 \mathrm{AU}$ ml-1 was recorded in MRS medium using LAB isolates. When MRS medium was substituted with $3.5 \%$ of lactose as a carbon source an increase in bacteriocin production to $2500 \mathrm{AU}$ $\mathrm{ml}-1$ was observed. (plate 10). There was a slight increase in bacteriocin activity by addition of $3.0 \%$ each of sucrose and maltose in the medium. It was observed that the production organism has an efficient enzyme machinery to utilize disaccharides [Table-11].

As shown in [Table-12] various supplements in MRS medium were also carried out for the production of bacteriocin. It was found that there was no effect on bacteriocin activity by the addition of 0.25 $0.50 \%$ of SDS and $2 \%$ of yeast extract. There was slight increase in the bacteriocin activity by addition of $1 \%$ Tween 80 and $0.05 \%$ of $\mathrm{MgSO}_{4}$.

Table 12- Bacteriocin activity of L. plantarum with different supplements in MRS medium

\begin{tabular}{|lccc|}
\hline MRS Substitutes & Concentration (\%) & Final pH & Activity (Aumn-1-1) \\
\hline MRS + Yeast extract & 2 & 4.27 & 50 \\
MRS + Tween80 & 1 & 4.19 & 100 \\
& 2 & 4.09 & 100 \\
MRS + MgSo 4 & 0.05 & 4.07 & 100 \\
MRS +SDS & 0.25 & 5.86 & 50 \\
\hline
\end{tabular}

\section{Quantitative Estimation of Protein using Lowry, et al. Method}

The quantitative estimation of protein was studied using Lowry, et al. method. These studies showed that all the 4 LAB isolates showed the presence of protein content and the quantitative estimation was carried out using UV- spectrophotometer with the OD values read at $650 \mathrm{~nm}$ and the results are shown in [Table-13].

Table 13- Estimation of protein

\begin{tabular}{|lllll|}
\hline & & & & \multicolumn{2}{c}{ OD at 650nm } \\
S. No & LAB isolates & Standard (BSA solution) & LAB & STD \\
\hline 1 & L.plantarum & S1(0.2) & 1.34 & 0.12 \\
2 & L.fermenturm & S2(0.4) & 1.19 & 0.15 \\
3 & L.casei & S3(0.6) & 0.89 & 0.19 \\
4 & L.brevis & S4(0.8) & 0.92 & 0.2 \\
\hline
\end{tabular}

Partial Purification and Molecular Size Determination Samples by TRICINE-SDS PAGE

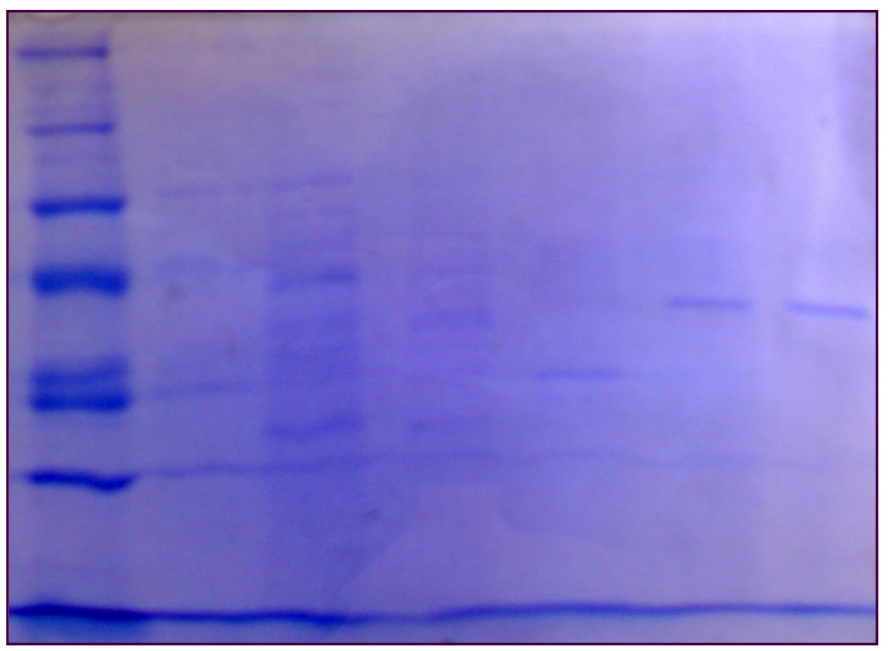

Fig. 6- Molecular weight determination by SDS-PAGE
A significant increase in yield and purification fold of the bacteriocin in study was observed during different purification stages. The crude supernatant fluid of 4 different were concentrated before subjected them to four rounds $(0-20,20-40,40-60$ and $60-80 \%)$ of ammonium sulphate precipitations. All the activity was recovered in the pellet at $80 \%$ saturation.

Attempts to size the bacteriocin under denaturing conditions were obscured due to diffuse banding. However under non-denaturing conditions the exact location of the protein giving activity was detected. The bacteriocin of $L$. plantarum was resolved as a single band of approximately $37 \mathrm{KDa}$ while that of $L$. fermentum appeared to be $8 \mathrm{KDa}$ [Fig-6].

\section{Qualitative Analysis of Antimicrobial Compounds by TLC}

After exposure to ninhydrin, pink color spots similar to the standard amino acids were observed. And the Rf value was determined as $0.54,0.34$ and 0.11 .

$$
\text { Rf value }=\frac{\text { Distance travelled by the solute from the origin }}{\text { Distance travelled by the solvent from the origin }}
$$

Table 14- Experimental Rf data for antimicrobial compounds isolated from $L A B$ isolates

\begin{tabular}{|llcc|}
\hline S. No & Detector reagent & LAB isolates & Rf values \\
\hline 1 & \multirow{2}{*}{ Ninhydrin } & L. plantarum & 0.54 \\
& & & 0.34 \\
& & 0.11 \\
\hline
\end{tabular}

\section{High Performance Liquid Chromatography}

The high performance liquid chromatography was performed for $L$. plantarum. The sample was made to run for $10 \mathrm{~min}$ and the volume of sample taken for analysis is $10 \mu \mathrm{l}$ and the analysis was made at $200 \mathrm{~nm}-320 \mathrm{~nm}$. Methanol was used as the solvent system for the study. After the analysis, peaks was obtained as shown in [Table15].

Table 15- HPLC for L. plantarum

\begin{tabular}{|lcccc|}
\hline S. No & RT & Area & \% Area & Height \\
\hline 1 & 3.469 & $3.5 \mathrm{E}+07$ & 23.73 & 1430580 \\
2 & 3.732 & $3.1 \mathrm{E}+07$ & 21.54 & 1694336 \\
3 & 4.197 & $1.9 \mathrm{E}+07$ & 13.31 & 1661178 \\
4 & 4.353 & $3.9 \mathrm{E}+07$ & 26.61 & 1921461 \\
5 & 4.937 & $1.5 \mathrm{E}+07$ & 10.3 & 471870 \\
6 & 6.493 & 3591438 & 2.47 & 147201 \\
7 & 7.029 & 2979136 & 2.05 & 113079 \\
\hline
\end{tabular}

*The results were compared with the standard.

\section{Discussion}

The present investigation highlights the isolation and characterization of bacteriocin producing $L A B$ strains from fermented foods and were screened for bacteriocin production, from which four bacteriocinogenic strains were identified and selected for further study, representing four isolates of $L$. plantarum, $L$. fermentum, $L$. brevis and $L$. casei. This would indicate that a wide variety of bacteriocinproducing $L A B$ are present on fermented milk, which therefore represent an abundant resource of such potentially useful bacteria. To date, only few bacteriocin producing $L A B$ has been reported in fermented foods [28].

The bacteriocin produced by $L$. plantarum and $L$. fermentum exhibited a wider spectrum of inhibition compared to the bacteriocin produced by $L$. brevis. The potential of these bacteriocins to inhibit the pathogens such as E. coli, S. aureus, S. typhi, Pseudomonas and Klebsiella makes it of crucial interest especially in processed foods 
where there is risk of food pathogens. Due to the phenomenon of immunity the bacteriocin from the producer organism were resistant to the organism producing it. Their antagonistic property is attributed to the low $\mathrm{pH}$, the undissociated acid and production of other primary and secondary antimicrobial metabolites [29].

The antimicrobial effect exerted by $L A B$ is the production of lactic acid and reduction of $\mathrm{pH}$, and acetic acid, diacetyl, hydrogen peroxide, fatty acids, aldehydes and other compounds [30]. Many LAB are resistant to antibiotics. This resistance's attributes are often intrinsic and nontransmissible [31]. L. plantarum was resistant to all of the antibiotics used in this study but $L$. brevis isolate was susceptible to all of the antibiotics.

Exposure of the bacteriocin samples to UV resulted in an increase in the bacteriocin titre. This might be due to the effect of UV on the permeability of the cell membrane. It has also been suggested that the dispersion of the bacteriocin complex into active subunits ultimately results in more lethal hits and consequently enhanced activity is witnessed [32].

According to Tagg, et al., [33] bacteriocins differ greatly with respect to sensitivity to $\mathrm{pH}$. Many of them are considerably more tolerant to acid than alkaline $\mathrm{pH}$ values. In the present study, bacteriocin produced by the $L$. plantarum exhibited the same profile and was active at $\mathrm{pH}$ values between 3-9. Maximum inhibitory activity was demonstrated at $\mathrm{pH}$ values between 5 to 6.5 . The optimum temperature and $\mathrm{pH}$ for the production of lactic acid by the test isolates was at $60^{\circ} \mathrm{C}$ and $\mathrm{pH} 6.5$.

The phenomenon of heat stability of LAB bacteriocins have been reported earlier for bacteriocin produced by $L$. brevis $0 \mathrm{G1}$ [2]. The findings are also in agreement with the above mentioned reports as observed heat stability of $L$. plantarum bacteriocin. The retention of activity by this bacteriocin after heating at $121^{\circ} \mathrm{C}$ for $30 \mathrm{~min}$, placed it within heat stable low molecular weight group of bacteriocins. This quality of the bacteriocin makes it superior in processed food stuffs where high heat is applied.

The number of chromatographic steps varies from three or more, for bacteriocin in the present study in which antibacterial activity was recovered after simple precipitation with ammonium sulfate from the cell-free culture supernatant fluid. The final reversed-phase HPLC step of the purification procedure led to isolation of a single active fraction having antibacterial activity. Bioautography on thinlayer chromatograms, a method previously used for detecting antibacterial and antifungal substances for control of pathogens was useful to revel the active fraction [34].

The study indicated that the isolated Lactobacillus species meet several of the criteria for use as a probiotic. The bacteriocins produced by $L$. plantarum and $L$. fermentum showed prominent antimicrobial properties, heat resistance and acid tolerant indicating strong probiotic potential hence these isolates can be use in the protection and improvement of intenstinal microbial flora and contribute health benefits to consumers.

\section{References}

[1] Brookes R.M. and Buckle A.E. (1992) The Lactic Acid Bacteria, 1, Elsevier Sci. Pub., London.

[2] Ogunbanwo S., Sanni A. and Onilude A. (2003) Afr. J. Biotechnol., 2(7), 179-184.

[3] Piard J.C. and Desmazeaud M. (1991) Lait, 71, 525-541.

[4] Brook T.M.T and Madigan (1991) Host-microbe Relationships and Disease Processes in Biology of Microorganisms., 6th ed. Prentice Hall Publicity Inc., 379-380.

[5] Prescott M. Harley and Kelvin O. (2005) Microbiology, McGraw Hill Inc. International ed., 511-517.

[6] Narayanan N., Roychoudhury and Srivastava A. (2004) Electronic Journal of Biotechnology, 7(1).

[7] Datta R. (1995) FEMS Microbiol. Rev., 16, 221-231.

[8] Zhennai Y. (2000) Antimicrobial Compounds and Extracellular Polysaccharides Produced by LAB: Structure and Properties, Academic Dissertation, Department of Food Technology, University of Helsinki, 61.

[9] Oyetayo V.O., Adetuyi F.C. and Akinyosoye F.A. (2003) Afr. J. Biotech. 2, 448-452.

[10]Brink ten B., Minekns M., Vander Vossen, Leer R.J. and Huis J.H.J. (1994) J. Appl. Bacteriol., 77, 140-148.

[11]Aly Savadogo., Cheik A.T., Ouattara Imael, Bassole H.N., Alfred S. Traore (2004) Pakistan Journal of Nutrition, 3(3), 174179.

[12]Nes I.F., Diep D.B., Halvarstein L.S., Brurberg M.B., Eijsink V. and Holo H. (1996) Antonie Van Leeuwenhoek, 70, 113-128.

[13]Garneau S., Martin N.I. and Vederas J.C. (2002) Biochimie, 84, 544-592.

[14]Montville T.J., Winkowski K. and Ludescher R.D. (1995) International Dairy Journal, 5, 797-814.

[15]Collins J.W., La Ragione R.M and Woodward M.J. (2009) Prebiotics and Probiotics Science and Technology, New York, NY USA, 1123-1192.

[16]Hammes W.P. and Ga"nzle M.G. (1998) Microbiology of Fermented Foods, 199-216.

[17]Bogovii MatijaSid B., Koman Rajgp M., Perko B., Rogelj I. (2007) Int. Dairy J., 17(2), 157-166.

[18]Larsen A.G., Vogensen F. and Josephsen J. (1993) J. of Appl. Microbiology, 75(2), 113-122.

[19]Axelsson L. (2004) Lactic Acid Bacteria: Microbiological and Functional Aspects. 1-66.

[20]Savadogo A., Ouattara Cheik A.T., Bassole Imael H.N and Traore S.A. (2004) Pak. J. Nutr., 3(3), 174-179.

[21]De Man J.C, Rogosa M., Sharpe M.E. (1960) J. Appl. Bacteriol., 23, 130-135.

[22]Howells B.W. (1992) Functions of Fermented Milk Challenges for the Health Science., Elsevier Sci. Publishers Ltd., 119-128.

[23]Halami P.M., Chandrashekar A. and Joesph R. (1999) Food Biotechnol., 13(2), 121-136.

[24]National Committee for Clinical Laboratory Standards (1999) Performance Standards for Antimicrobial Susceptibility Testing: Ninth Information Supplement, NCCLS Document M100-S9., Wayne.

[25]Association of Analytical Communities International (2002) Official Methods of Analysis of AOAC, 17th ed., Gaithersburg, MD, USA.

[26]Wanda J. and Bonita A. (1991) Appl. Environ. Microbiol., 57, 701-706.

[27]Sadisivam S. and Manikam M. (2005) Biochemical Methods, New Age International Ltd., New Delhi, 256. 
[28]Todorov S. and Dicks L.M.T. (2005) J. Microbiol., 370-374(s).

[29]Ten Brink B., Minekus M., Vander Vossen J.M.B.M., Leer R.J. and Huis J.H.J. (1994) J. Applied Bacteriol., 77, 140-148.

[30]Jay J. (2000) Modern Food Microbiology, 6th ed., Aspen, Maryland.

[31]Curragh H.J. and Collins M.A. (1992) Journal of Applied Bacteriology, 73, 31-36.

[32]Muriana P.M. and Klaenhammer T.R. (1991) Appl. Environ. Microbiol., 57, 114-121.

[33]Tagg J.R., Dajani A.S. and Wannamaker L.W. (1976) Bacteriol, Rev., 40, 722-756.

[34]Vodnar D.C., Paucean A., Dulf F.V., Socaciu C. (2010) Not. Bot. Hort. Agrobot. Cluj., 38(1), 109-113.

[35]Fortina M.G., Parini C., Rossi P.R. and Magnhim P.H. (1973) Letters in App. Microbiol., 17, 303-306.

[36]Sanni A.l., Ahrne S. and Onilude A.A. (1995) J. Basic Microbiol., 29(6), 427- 432. 